\title{
The US Medical Liability System: Evidence for Legislative Reform
}

\author{
Janelle Guirguis-Blake, $M D^{1}$ \\ George E. Fryer, $P b D^{2}$ \\ Robert L. Pbillips Jr, MD, MSPH ${ }^{3}$ \\ Ronald Szabat, JD, LLM \\ Larry A. Green, $M D^{3}$ \\ 'Tacoma Family Medicine Residency Pro- \\ gram, Department of Family Medicine, \\ University of Washington, Seattle, Wash \\ ${ }^{2}$ Department of Pediatrics, New York Uni- \\ versity School of Medicine, NYU Center \\ for Child Health Research, New York, NY \\ ${ }^{3}$ Robert Graham Center, Washington, DC \\ ${ }^{4}$ American Society of Anesthesiologists, \\ Washington, DC
}

\section{shin \\ MORE ONLINE
www.annfammed.org}

Conflicts of interest: none reported

\section{CORRESPONDING AUTHOR}

Janelle Guirguis-Blake, MD

Tacoma Family Medicine

Residency Program

521 Martin Luther King Jr Way

Tacoma, WA 98405

jguirgui@u.washington.edu

\begin{abstract}
BACKGROUND Despite state and federal efforts to implement medical malpractice reform, there is limited evidence on which to base policy decisions. The National Practitioner Data Bank (NPDB) offers an opportunity to evaluate the effects of previous malpractice tort reforms on malpractice payments and premiums.

METHODS For every state and the District of Columbia, we calculated the number of malpractice payments, total amount paid, and average payment from NPDB data reported from 1999 through 2001. We analyzed 44,913 claims using logistic regression to study associations between payments, physician premiums, and 10 state statutory tort reforms.
\end{abstract}

RESULTS Wide variations exist in malpractice payments among states. The reforms most associated with lower payments and premiums were total and noneconomic damage caps. Mean payments were $26 \%$ lower in states with total damage caps $(\$ 196,495.34$ vs $\$ 265,554.50, P=.001)$. Mean payments were $22 \%$ less in states with noneconomic damage caps $(\$ 219,225.98$ vs $\$ 279,849.86, P=.010)$. Total damage caps were associated with lower mean annual premiums, especially for obstetricians $(\$ 22,371.57$ vs $\$ 42,728.68$, $P<.001)$. Hard noneconomic damage caps were associated with premium reductions for obstetricians $(30,283.75$ vs $45,740.88 ; P=.039)$.

CONCLUSIONS Significant reductions in malpractice payments could be realized if total or noneconomic damage caps were operating nationally. Hard noneconomic damage and total damage caps could yield lower premiums. If tied to a comprehensive plan for reform, the money saved could be diverted to implement alternative approaches to patient compensation or be used to achieve other systems reform benefiting patients, employers, physicians, and hospitals.

Ann Fam Med 2006:4:240-246. DOI: 10.1370/afm.535.

\section{INTRODUCTION}

$\mathrm{R}$ ecent increases in malpractice premiums, exorbitant malpractice awards, and physicians' fear of litigation have been reported as facdriving rising health care costs and threatening access to medical care in the United States. ${ }^{1}$ By no means is the United States unique; several countries have begun to see sharp rises in malpractice payments and premiums threatening malpractice insurers' solvency and patients' access to services. ${ }^{2-5}$ During each medical malpractice crisis of the past 3 decades, stakeholders have debated the causes and proposed legislative solutions. ${ }^{6}$ Wide disparities have been documented in rates of malpractice claims filed, average payments per claim, and maximum claim payments among states. ${ }^{7}$ Although cost containment is only one goal of medical liability reform, it remains a major driver of policy debates.

Studies analyzing data from the crises in the 1970s and 1980s have shown that state statutory reforms, specifically caps on noneconomic damages and collateral source offsets, are associated with lower total payments, although some of these studies have shown mixed results. ${ }^{8-11}$ Noneconomic 
damage caps and limitations on time to file suits have been associated with lower malpractice premiums. ${ }^{12}$ Most studies were conducted more than a decade ago, however, and were limited to samples of insurance companies. Given contemporary medical liability concerns, it is important to learn from recent experience and use more complete data to assess the associated effects of state tort reform on the state malpractice payment and premium variability that frame our current crisis.

We analyzed all payments made to settle claims or satisfy malpractice judgments on behalf of physicians in the United States for the years 1999 through 2001 as reported to the National Practitioner Data Bank (NPDB). These dates were chosen because many states instituted reforms in the mid-1990s, and we sought to capture subsequent claims data taking into account delays in data reporting, as well as lags in application of these reforms (eg, possible delays because of appeals). We also sought to capture a period after the first wave of reforms but before the second wave of reforms that occurred after 2001. We evaluated malpractice payments and medical liability premiums in relation to 10 common state tort statutes that originally were intended to curb claims. We also assessed the potential direct economic impact of implementing effective statutory reforms nationwide.

\section{METHODS}

In 1986 Congress enacted legislation to create the NPDB as a repository of medical malpractice payments and adverse actions related to limitations on licensure, clinical privileges, professional society membership, and participation in federal programs. ${ }^{13}$ According to this legislation, malpractice carriers, hospitals, professional societies, and state licensing boards are mandated to report to the NPDB all malpractice payments made to settle claims or satisfy judgments against individual nurses, dentists, and physicians. The original intent of the databank was to improve health care by encouraging licensing boards, health care facilities, and professional societies not only to identify and discipline those who provide incompetent care, but also to limit the ability of those clinicians to change locations without making known any previous medical malpractice payment and adverse action history. ${ }^{14}$

We analyzed the 44,913 paid medical malpractice claims reported on behalf of physicians to the NPDB between January 1999 and December 2001 (public use data files). To standardize these total claims for numbers of physicians and people in each state, we used information from the 2000 American Medical Association (AMA) Physician Masterfile ${ }^{15}$ and the 2000 US Decennial Census. ${ }^{16}$ We calculated the reported number of medical malpractice payments, total dollar amount payments, mean dollar amount per payment, payments per 1,000 practicing physicians, and payments per 100,000 population. The payments were divided by the number of practicing physicians based on the state in which the physicians practiced. Likewise, we standardized payment amount by state population to provide an estimate of payments per person living in each state. State statutes were assessed as of January 1999 and were obtained from the AMA, ${ }_{17}$ Physician Insurers of Association of America, ${ }_{1}^{18}$ and American Tort Reform Association. ${ }^{19}$ We developed a coding scheme to categorize each state and the District of Columbia by the presence or absence of specific malpractice statutory reform. Two teams (one team included an attorney) independently coded state tort reform statutes, and the teams decided on the final coding by consensus.

Bivariate analysis was performed to study associations between malpractice payment rates/payments and physician liability premiums (dependent variables) and 10 common state tort reform statutes (independent variables). These state statutory reforms included total damage caps, noneconomic damage caps, joint liability reform, attorney fee caps, mandatory arbitration, excess coverage funds, permitted periodic payments, collateral source reform, certificate of merit requirements, and statute of limitations. Total damage caps are limits on total damages, which include economic damages (ie, medical bills, lost income, direct cost of injury) and noneconomic damages (ie, caps for "pain and suffering"). "Hard" noneconomic damage caps are those without any exceptions; "soft" noneconomic damage caps are those with exceptions (including adjustment for inflation, exceptions for particular injuries). (Supplemental Appendix 1, available onlineonly at http://www.annfammed.org/cgi/content/ full/4/3/240/DC1, displays a complete list of statute definitions.) Because total damage caps showed a consistent and strong relationship across multiple payment characteristics, we controlled for the presence of total damage caps for all statutes that showed significant associations across one or more payment characteristics. We performed a multivariate analysis (with regression equations using each variable individually and then using all variables in combination); this multivariate analysis did not add further explanation to our model of the association between caps, payments, and premiums. Statute variables (other than total and noneconomic damage caps) did not obscure the effects of caps, nor did they add explanation to the model. We therefore report results from the bivariate analysis. We used the source for state medical premium information commonly cited by US General Accounting Office 
and US Congressional Budget Office and extracted annual premiums for 3 specialties for which information was available: internal medicine, obstetrics, and general surgery. ${ }^{20}$ Pearson's coefficient was calculated for associations between payment characteristics and premiums. To calculate reductions in liability payments associated with certain statutes, we standardized the rates where we applied payment and premium characteristics of states with a specific statute to those states without that statute.

\section{RESULTS}

\section{Payments}

Wide variations in mean malpractice payment characteristics exist among the states (Table 1). For the years 1999 through 2001, the average dollar amount per payment ranged from $\$ 113,695$ in Michigan to
$\$ 560,059$ in the District of Columbia. Total payments for the 3-year period ranged from $\$ 15.4$ million in Wyoming to more than $\$ 1.8$ billion in New York. Payment characteristics of all 50 states and the District of Columbia are displayed in Supplemental Table 1, available online-only at http://www.annfammed. org/cgi/content/full/4/3/240/DC1.

When the 10 different state statutory reforms were studied using bivariate analysis, associations were found between 2 reforms — total damage caps and noneconomic damage caps - and payments. Total damage caps were negatively associated with the mean dollar amount per payment, payment per practicing physician, and payment per person in the population (Table 2). The mean dollar amount per payment was $26 \%$ lower in those 7 states having total damage caps compared with those 44 states not having total damage caps $(\$ 196,495.34$ vs $\$ 265,554.50, P=.001)$. Total

Table 1. States with the Lowest and Highest Dollar Amount per Payment, 1999-2001

\begin{tabular}{|c|c|c|c|c|c|}
\hline State & $\begin{array}{l}\text { Average } \\
\text { Malpractice } \\
\text { Payment } \\
\text { (\$) }\end{array}$ & $\begin{array}{c}\text { Total Payments } \\
\text { 1999-2001 } \\
\text { (\$) }\end{array}$ & $\begin{array}{l}\text { Payment } \\
\text { per Person* } \\
(\$)\end{array}$ & $\begin{array}{c}\text { Payments per } \\
\text { 1,000 Physicians } \\
\text { No. }\end{array}$ & $\begin{array}{c}\text { Payments per } \\
100,000 \text { Population }{ }^{\ddagger} \\
\text { No. }\end{array}$ \\
\hline Michigan & 113,695 & $243,762,850$ & 24.53 & 89.28 & 21.57 \\
\hline Kansas & 150,592 & $68,670,050$ & 25.54 & 80.32 & 16.96 \\
\hline California & 151,744 & $647,035,900$ & 19.10 & 56.44 & 12.59 \\
\hline Nebraska & 160,882 & $35,233,100$ & 20.59 & 60.13 & 12.80 \\
\hline New Mexico & 172,666 & $54,389,750$ & 29.90 & 85.32 & 17.32 \\
\hline Alabama & 379,261 & $72,818,100$ & 16.37 & 22.26 & 4.32 \\
\hline Massachusetts & 382,324 & $343,709,250$ & 54.14 & 39.95 & 14.16 \\
\hline Illinois & 418,087 & $664,341,000$ & 53.49 & 51.10 & 12.79 \\
\hline Connecticut & 472,984 & $222,775,300$ & 65.42 & 44.08 & 13.83 \\
\hline District of Columbia & 560,059 & $104,731,000$ & 183.08 & 53.69 & 32.69 \\
\hline
\end{tabular}

Table 2. Payment Characteristics of States With and Without Total Damage Caps, 1999-2001

\begin{tabular}{|c|c|c|c|c|c|}
\hline States & $\begin{array}{l}\text { Payments per } \\
1,000 \text { Physicians* } \\
\text { No. }\end{array}$ & $\begin{array}{c}\text { Payments } \\
\text { per 100,000 } \\
\text { Populationt } \\
\text { No. }\end{array}$ & $\begin{array}{l}\text { Average } \\
\text { Malpractice } \\
\text { Payment } \\
\text { (\$) }\end{array}$ & $\begin{array}{l}\text { Payment per } \\
\text { Physician } \\
\text { (\$) }\end{array}$ & $\begin{array}{l}\text { Payment } \\
\text { per Person } \$ \\
\text { (\$) }\end{array}$ \\
\hline \multicolumn{6}{|l|}{ States with total caps $(\mathrm{n}=7)$} \\
\hline Median & 60.13 & 12.80 & $190,174.62$ & $10,833.56$ & 20.95 \\
\hline Mean & 60.58 & 12.86 & $196,495.34$ & $11,504.69$ & 24.38 \\
\hline \multicolumn{6}{|c|}{ States without total caps $(n=44)$} \\
\hline Median & 55.06 & 12.74 & $248,349.27$ & $13,629.10$ & 30.55 \\
\hline Mean & 61.05 & 14.40 & $265,554.50$ & $15,501.78$ & 38.73 \\
\hline$P$ value for mean differences & .958 & .451 & .001 & .015 & .006 \\
\hline \multicolumn{6}{|c|}{$\begin{array}{l}\text { *Number of payments per 1,000 practicing physicians in those states (AMA } 2000 \text { Masterfile). } \\
\text { †Number of payments per general population in those states ( } 2000 \text { Census Bureau Data). } \\
\text { † Total payment dollar amount per number of practicing physicians in those states (AMA } 2000 \text { Masterfile). } \\
\text { § Total payment dollar amount per general population in those states ( } 2000 \text { Census Bureau). }\end{array}$} \\
\hline
\end{tabular}


damage caps were not associated with fewer numbers of payments per physician or per person.

Noneconomic damage caps were significantly associated with lower payments, including lower mean dollar amounts per payment, payment per practicing physician, and payment per person in the population (Table 3). The average amount per payment was $22 \%$ less for those states with noneconomic caps than it was for those states without noneconomic caps $(\$ 219,225.98$ vs $\$ 279,849.86, P=.010)$. Controlling for the presence of total damage caps, this association remained statistically significant $(P=.029)$. When payments were divided by the state population, the dollar amount per person in the population was onethird less in states having noneconomic caps compared with states not having noneconomic caps ( $\$ 28.60$ vs $\$ 42.02$ per person, $P=.047)$. When controlled for total damage caps, these differences in number of payments per person were not statistically significant, $P=.226$. As with total caps, there was no difference between states with and without noneconomic damage caps in the number of payments made per physician or per person in the population. We then split noneconomic damage caps into hard and soft caps to see whether this distinction mattered. The amount per claim differed significantly between states not having a noneconomic damage cap and those having a hard noneconomic damage cap $(\$ 279,849.86$ vs $\$ 194,543.66 ; P=.008)$.

Of the other 8 tort reform statutes, we found that states with periodic payments had higher dollar amounts per payment, and states with excess coverage funds had lower dollar amounts per payment. When controlled for whether a state had total damage caps, however, these associations lost statistical significance.

After rate standardization for mean payment rate and amount, had those 31 states without noneconomic damage caps adopted the payment characteristics of those 20 states with noneconomic damage caps, we estimated a $\$ 1.3$ billion reduction in malpractice payments during the 3-year period (1999-2001). Likewise, had those 44 states without total damage caps adopted the payment characteristics of those states with total damage caps, we estimated a potential $\$ 2.4$ billion payment reduction during the 3 years. The estimated reductions during the 3 -year period could be $\$ 1.0$ billion, $\$ 2.8$ billion, and $\$ 5.1$ billion if total caps of $\$ 1$ million, $\$ 500 \mathrm{~K}$, and $\$ 250 \mathrm{~K}$, were applied, respectively, to all payments.

\section{Liability Premiums}

Bivariate analysis for each of the 10 state statutes and physician malpractice premiums showed the strongest associations between total damage caps and lower premiums (Table 4). Total damage caps were associated with lower mean annual premiums for all 3 specialties, with obstetricians having the greatest savings $(\$ 22,371.57$ vs $\$ 42,728.68, P<.001)$. Although undifferentiated noneconomic damage caps showed a trend toward lower physician liability premiums, this trend was not statistically significant (Table 4 ). When we further differentiated hard from soft noneconomic damage caps, we found that the premiums for obstetricians varied significantly $(\$ 30,283.75$ vs $\$ 45,740.88 ; P=.039)$ (Table 5).

If those 44 states without total caps had premium rates of states with total caps, the potential annual premium savings for internists, general surgeons, and obstetricians could be $\$ 711$ million, $\$ 270$ million, $\$ 815$ million, respectively. Likewise, for those 31 states without noneconomic damage caps, the potential annual premium savings for internists, general surgeons, and obstetricians could be $\$ 539$ million, $\$ 127$ million, $\$ 350$ million, respectively.

Table 3. Payments in States With and Without Noneconomic Damage Caps, 1999-2001

\begin{tabular}{|c|c|c|c|c|c|}
\hline States & $\begin{array}{l}\text { Payments per } \\
\text { 1,000 Physicians* } \\
\text { No. }\end{array}$ & $\begin{array}{c}\text { Payments } \\
\text { per 100,000 } \\
\text { Population }{ }^{-} \\
\text {No. }\end{array}$ & $\begin{array}{l}\text { Average } \\
\text { Malpractice } \\
\text { Payment } \\
\text { (\$) }\end{array}$ & $\begin{array}{l}\text { Payment per } \\
\text { Physician }{ }^{\ddagger} \\
\text { (\$) }\end{array}$ & $\begin{array}{l}\text { Payment } \\
\text { per Person } \$ \\
(\$)\end{array}$ \\
\hline \multicolumn{6}{|c|}{ States with noneconomic caps $(\mathrm{n}=20)$} \\
\hline Median & 56.79 & 13.38 & $217,406.03$ & $11,464.87$ & 25.79 \\
\hline Mean & 62.74 & 13.84 & $219,225.98$ & $12,711.68$ & 28.60 \\
\hline \multicolumn{6}{|c|}{ States without noneconomic caps ( $\mathrm{n}=31$ ) } \\
\hline Median & 54.08 & 12.65 & $254,058.74$ & $16,940.11$ & 31.25 \\
\hline Mean & 59.85 & 14.42 & $279,849.86$ & $16,399.28$ & 42.02 \\
\hline$P$ value & .691 & .776 & .010 & .028 & .047 \\
\hline \multicolumn{6}{|c|}{$\begin{array}{l}\text { *Number of payments per 1,000 practicing physicians in those states (AMA } 2000 \text { Masterfile). } \\
\text { †Number of payments per general population in those states ( } 2000 \text { Census Bureau Data). } \\
\text { † Total payment dollar amount per number of practicing physicians in those states (AMA } 2000 \text { Masterfile). } \\
\S \text { Total payment dollar amount per general population in those states (2000 Census Bureau Data). }\end{array}$} \\
\hline
\end{tabular}




\begin{tabular}{|c|c|c|c|c|c|c|}
\hline Specialty & $\begin{array}{l}\text { States With Total } \\
\text { Caps }(\mathrm{n}=7) \\
\$\end{array}$ & $\begin{array}{l}\text { States Without } \\
\text { Total Caps } \\
(n=44) \\
\$\end{array}$ & $\begin{array}{c}P \\
\text { Values }\end{array}$ & $\begin{array}{c}\text { States With } \\
\text { Noneconomic Caps } \\
(n=20) \\
\$\end{array}$ & $\begin{array}{c}\text { States Without } \\
\text { Noneconomic Caps } \\
(\mathrm{n}=31) \\
\$\end{array}$ & $\begin{array}{c}P \\
\text { Values }\end{array}$ \\
\hline Internal medicine & $4,519.86$ & $7,447.00$ & .015 & $6,461.65$ & $7,421.74$ & .427 \\
\hline General surgery & $16,912.14$ & $24,516.93$ & .051 & $22,244.62$ & $24,092.16$ & .665 \\
\hline Obstetrics & $22,371.57$ & $42,728.68$ & .001 & $36,051.81$ & $42,171.97$ & .371 \\
\hline
\end{tabular}

Table 5. Mean Annual Premiums by Specialty for States With and Without Hard or Soft Noneconomic Caps, 2000

\begin{tabular}{|c|c|c|c|c|c|}
\hline \multirow[b]{2}{*}{ Specialty } & \multirow{2}{*}{$\begin{array}{l}\text { States With Hard } \\
\text { Noneconomic Caps* } \\
\left(\begin{array}{c}(\mathrm{n}=12) \\
\$\end{array}\right.\end{array}$} & \multirow{2}{*}{$\begin{array}{l}\text { States With Soft } \\
\text { Noneconomic Caps* } \\
\left(\begin{array}{c}(n=8) \\
\$\end{array}\right.\end{array}$} & \multirow{2}{*}{$\begin{array}{c}\text { States Without } \\
\text { Noneconomic Caps } \\
(n=31) \\
\$\end{array}$} & \multicolumn{2}{|c|}{$P$ Values ${ }^{\dagger}$} \\
\hline & & & & $\begin{array}{l}\text { Hard vs } \\
\text { Soft Caps }\end{array}$ & $\begin{array}{l}\text { Hard vs } \\
\text { No Caps } \\
\end{array}$ \\
\hline Internal medicine & $5,814.75$ & $7,432.00$ & $7,421.74$ & .157 & .430 \\
\hline General surgery & $20,653.08$ & $25,304.50$ & $24,092.16$ & .157 & .446 \\
\hline Obstetrics & $30,283.75$ & $45,740.88$ & $42,171.97$ & .039 & .081 \\
\hline
\end{tabular}

\section{DISCUSSION}

This study is the first to use the most comprehensive national medical liability payment data available to investigate the relationships between 10 specific state tort statutory reforms and malpractice payments and premiums. For the years 1999 through 2001, total and noneconomic damage caps were associated with lower dollar amounts per payment, confirming findings from smaller and less-recent studies. ${ }^{8-10}$ An important new finding is the association between total caps and lower insurance premiums; there is a suggestion that hard noneconomic damage caps are also associated with lower insurance premiums. This association is not surprising and calls into serious question the argument that recent increases in medical liability premiums are unrelated to payments. Currently, there remains considerable discourse regarding the multiple factors influencing the financial losses seen by malpractice carriers (eg, market cycle, claims severity and frequency, investment returns) and associations with rises in premiums. ${ }^{21}$

It is important to begin a discussion of limitations of this study by stating the controversies that surround the NPDB. ${ }^{22}$ In 2000, the General Accounting Office made recommendations regarding the limitations of the NPDB, especially with regard to its findings of delayed submissions (more than 30-day delays), miscoding of information, lack of information about nonphysician clinicians, and systems' use of the corporate shields to avoid reporting. Our use of aggregate data from a 3 -year period minimizes issues around submission delays, we did not use specific claims information (subject to coding errors), and we were interested only in payments by physician clinicians. NPDB data represent payments made only on behalf of individual practitioners; therefore, we were unable to include payments made on behalf of corporations (eg, corporate shield technicality) or errors in double reporting. Despite these limitations of the NPDB, it remains the most complete source of payment data available.

None of the tort statutory reforms we studied was associated with lower rates of payments (ie, fewer payments per physician or per population). Because the NPDB is a repository for payments and not claims, claims that do not result in payments are not reported. Accordingly, some reforms may be associated with lower claims rates, an association that cannot be tested using the NPDB. There are instances in which the NPDB may report multiple payments for one claim (ie, by the insurance company as well as a state fund) in those states that have excess coverage funds. To ensure that mean dollar amounts per payment were not falsely decreased in states with excess coverage funds and caps, we repeated the analysis removing all 10 states with excess coverage funds and found that the same relationships between total caps and noneconomic caps and lower mean claim payment remained significant. Likewise, the association between total caps and lower premiums for obstetricians remained significant.

Conclusions of causation must be made cautiously because of complex, interacting, and other unmeasured 
factors. For example, the nonsignificant tendency for states mandating periodic payments to have higher malpractice payments might not mean that this reform leads to higher payments; rather, it might mean that states with high payouts have acknowledged a need to allow defendants to pay large awards over time. The lower payments and premiums in the 7 states that had total caps show a strong association between payments and caps despite a small sample size. Using dichotomous variables to describe other laws with subtle variations and major exceptions, however, may actually bias against finding significant associations where they may in fact exist, as any outcome differences are averaged.$^{23}$ As a result of this concern, we chose to define and analyze hard and soft noneconomic damage caps separately.

Although other tort reform statutes showed tendencies toward lower payments, significance vanished when we controlled for total damage caps. This finding may reflect an overwhelming effect of total damage caps on payments. Alternatively, as argued in a June 2004 Congressional Budget Office report, analyzing the effects of individual statutes is complicated by an inherent difficulty in controlling for other unmeasured differences between states; these differences may have important effects on premiums. ${ }^{24}$ In fact, Thorpe's recent analysis showed that the presence of caps is associated with lower physician malpractice premiums. ${ }^{21}$

Our estimates of payment reductions were limited to the direct savings, probably underestimating the financial impact of caps. Reductions in other indirect costs of litigation could generate considerable savings, as payments represent only a fraction of the total costs of medical liability. ${ }^{25}$ Our analysis supports the Congressional Budget Office estimates that tort reforms could increase federal revenues by $\$ 3$ billion and save $\$ 14.9$ billion over the next 10 years while reducing physician premiums by $25 \%$ to $30 \% .^{26}$

Given a sample size of 51 , this study is at risk of poor power to detect significant associations. We chose to use a traditional standard of $95 \%$ certainty but recognize that policy makers may not need such a rigorous standard and may be comfortable with a lower threshold of certainty, in which case other associations between reforms and malpractice payments might bear further scrutiny.

Time lags also presented a limitation; time from statute enactment to effective date varied from immediately to several months, and time from a statute's effective date to actual legal application could be years. Because most statutory reforms in the 1990s were enacted in the few years before 1999, we coded statute enactment as of January 1999 and analyzed payments made during the 3 subsequent years (1999-2001) in an effort to capture paid claims most likely affected by the statute. Future analyses could quantify payments and premiums before and after statute enactment to establish trends that may be explained by statute application.

Cost containment is certainly not the only goal of tort reform. The current medical liability tort system has failed clinicians and patients as a mechanism of rational compensation for injury and of improving the quality of care. ${ }^{27}$ The wide state-to-state variations in payments imply a lack of equitable compensation for injured patients. Previous studies have substantiated this failing and proposed innovative options for the malpractice tort system to promote justice and improve care. ${ }^{28}$ The United States could also learn from international models. In Spain, for example, the medical society and regional health service worked together to institute new systems to provide insurance coverage, professional education, and advice for physicians while continuing to protect and respect the rights of patients. ${ }^{29}$ Sweden has a no-fault system, which has been considered a model for US reform. ${ }^{30}$ For the United States, the sizable financial savings associated with total and noneconomic damage caps accrue not only to physicians but also to insurers, employers, and patients who ultimately bear these costs. Moving the current policy debates toward finding a broader solution to the inequities in our current liability system would mean that reform efforts would include strategies aimed at improving the quality and safety of the health system.

To read or post commentaries in response to this article, see it online at http://www.annfammed.org/cgi/content/full/4/3/240.

Key words: Liability, legal; malpractice; legal liability, premiums; cost control; insurance, liability

Submitted July 20, 2005; submitted revised December 4, 2005; accepted December 15, 2005.

Funding support: This research was performed by the Robert Graham Center funded by the American Academy of Family Physicians.

Disclaimer: The authors of this article are responsible for its contents. The information and opinions contained in research from The Robert Graham Center do not necessarily reflect the views or policy of The American Academy of Family Physicians. The views in this paper are the authors'.

Acknowledgments: The authors wish to thank Kimberly Horvath for her review of state malpractice tort statutes and advice on this manuscript, Lisa S. Klein for her assistance in manuscript preparation, and William Taylor for his advice on literature and database searching.

\section{References}

1. Office of Assistant Secretary for Planning and Evaluation. Department of Health and Human Services. Confronting the new health care crisis: improving health care quality and lowering costs by fixing our medical liability system. 2002. Available at: http://aspe.hhs gov/daltcp/reports/litrefm.htm. Accessed: 7 March 2005. 
2. Spurgeon D. Cost of malpractice insurance set to rise in Canada. BMJ. 2000;320:601.

3. Zinn C. Australian government forced to bail out medical malpractice insurer. BMJ. 2002;324:808.

4. Payne D. Irish government asked to pay obstetricians' insurance premiums. BMJ. 2001;322:512.

5. Iglesias-Rogers $\mathrm{G}$. Argentine doctors face more litigation from desperate patients. Lancet. 2002;360:1311.

6. Medical Malpractice Insurance: Multiple Factors Have Contributed to Increased Premium Rates. Washington, DC: General Accounting Office; 2003. GAO-03-702

7. Fanaeian N, Merwin E. Malpractice: provider risk or consumer protection? Am J Med Qual. 2001;16:43-57.

8. Sloan FA, Mergenhagen PM, Bovbjerg RR. Effects of tort reforms on the value of closed medical malpractice claims: a microanalysis. J Health Polit Policy Law. 1989;14:663-689.

9. Impact of Legal Reforms on Medical Malpractice Costs. Washington, DC. Government Printing Office: US Congress, Office of Technology Assessment; 1993. OTA-BP-H-119.

10. Danzon P. The frequency and severity of medical malpractice claims: new evidence. Law Contemp Problems. 1986;49:57-84.

11. Sloan FA. State responses to the malpractice insurance "crisis" of the 1970s: an empirical assessment. J Health Polit Policy Law. 1985; 9:629-646

12. Zuckerman S, Bovbjerg RR, Sloan F. Effects of tort reforms and other factors on medical malpractice insurance premiums. Inquiry. $1990 ; 27: 167-182$

13. US Department of Health and Human Services, Bureau of Health Professions, Division of Practitioner Data Banks. National Practitioner Data Bank Public Use Datafile. Available at: http://www.npdbhipdb.com/index.html. Accessed: 7 March 2005.

14. Oshel RE, Croft T, Rodak J. The National Practitioner Data Bank; the first four years. Public Health Reports. 1995;110:383-394.

15. American Medical Association Masterfile. American Medical Association; 2000.

16. Statistical Abstract of US 2000 Population. Washington, DC: US Dept of Commerce; 2000.
17. Advocacy Resource Center 1992, 2002, 2003 Compendiums. American Medical Association.

18. Physician Insurers Association of America State Enactments of Selected Health Care Liability Reforms. Rockville, Md: Physician Insurers Association of America; 2003.

19. Tort Reform Record. Washington, DC: American Tort Reform Association; 2002.

20. Medical Liability Monitor. 2000 Rate Survey of 3 Medical Specialties. Chicago, III: Medical Liability Monitor; 2000.

21. Thorpe KE. The medical malpractice 'crisis': recent trends and the impact of state tort reforms. Health Aff (Millwood). 2004; Suppl Web Exclusives:W4-20-30.

22. National Practitioner Data Bank: Major Improvements Are Needed to Enhance Data Bank's Reliability. Washington DC: General Accounting Office; 2000. GAO-01-130.

23. Danzon P. The frequency and severity of medical malpractice claims. J Law Economics. 1984;27:115-148.

24. The Effects of Tort Reform: Evidence from the States 2004. Washing ton, DC: Congressional Budget Office; 2004.

25. Report to Congressional Committees. Medical Liability Impact on Hos pital and Physician Cost Extends Beyond Insurance. Washington, DC: General Accounting Office; 1995. GAO/AIMD-95-169.

26. Congressional Budget Office. Congressional Budget Office cost estimate HR 5, Help Efficient, Accessible, Low-Cost, Timely Healthcare (HEALTH) Act of 2003. Available at: http://www.cbo.gov/ftpdocs/40xx/ doc4091/hr5.pdf. Accessed: 7 March 2005.

27. Localio AR, Lawthers AG, Brennan TA, et al. Relation between malpractice claims and adverse events due to negligence. Results of the Harvard Medical Practice Study III. N Engl J Med. 1991;325:245-251.

28. Corrigan JM, Greiner A, Erickson SM, eds. Fostering Rapid Advances in Health Care: Learning From System Demonstrations. Washington, DC: National Academy Press; 2002.

29. Trilla A, Bruguera M. Spain: avoiding lawsuits. Lancet. 2000;356:1266-1267

30. Studdert DM, Brennan TA. Toward a workable model of "no-fault" compensation for medical injury in the United States. Am J Law Med. 2001;27:225-252. 